\title{
Evaluating of Induction of Apoptosis by Cornus mass L. Extract in the Gastric Carcinoma Cell Line (AGS)
}

\author{
Farzaneh Sadat Hosseini ${ }^{1,2}$, Mojgan Noroozi Karimabad ${ }^{1}$, Mohammad Reza \\ Hajizadeh $^{1,2}$,Alireza Khoshdel ${ }^{2,3}$, Soudeh Khanamani Falahati-Pour ${ }^{3}$, Mohammad \\ Reza Mirzaei ${ }^{1,2}$, Seyed Mehdi Mirmohamadi ${ }^{1,2}$, Mehdi Mahmoodi ${ }^{1,2,4 *}$
}

\begin{abstract}
Aim and objectives: Natural products and derivatives of medicinal vegetation can play an important role to the cure tumor. The Present study was focused to determine the effect of Cornus mass L. extract on the induction of apoptosis in AGS gastric carcinoma cell line in compared to L929 cells. Methods: In this experimental study, AGS and L929 cells were cultured and treated with different concentrations $(0-10 \mathrm{mg} / \mathrm{ml})$ of Cornus mass L. extract for 48 and 72 hours. Cell proliferation was assessed by MTT assay. The optical density of the colored solution was quantified at $570 \mathrm{~nm}$ wavelengths by an ELISA Reader. Making use of the apoptosis detection kit of Annexin V-FITC, PI and double staining with Annexin V-FITC were carried out for flow cytometry investigations. Data were analyzed by ANOVA. Variations with a P-value less than 0.05 were considered significant. Results: shows a noticeable deviation among various concentrations of extract when cells were treated for 48, $72 \mathrm{~h}$ declined cell viability in AGS cell line in comparison L929 cell lines in a dose and time-dependent manner $(\mathrm{P}<0.05)$. This extract also displayed approximately several-fold increased anti-cancer potency in AGS compared to L929 cells. The $\mathrm{IC}_{50}$ value in AGS cells (evaluated after $48,72 \mathrm{~h})$ of the extract against AGS cells was $5 / 44,2 / 44 \mathrm{mg} / \mathrm{ml}(\mathrm{p} \leq 0.05)$. The analysis results of flow cytometry indicated that apoptosis was induced by the extract in AGS cells treated, compared with L929 cells. Conclusion: Each of our results implicates the reality that Cornus mass L. extract acts as a novel, potent inhibitor of cancer proliferation in in vitro. This may result in developing a promising therapeutic agent for the treatment of indole-sensitive cancers.
\end{abstract}

Keywords: Apoptosis- Gastric cancer- Cornus mass L. extract- L929 cells- AGS cell line

Asian Pac J Cancer Prev, 20 (1), 123-130

\section{Introduction}

Gastric cancer is regarded as the 4th most prevalently happening fatal disease universally (Kamangar et al., 2006) and the second major reason for deaths caused by cancer (Jemal et al., 2010). In East Asian countries like South Korea, Japan and China, the highest rate of the fatalities has been reported for gastric cancer. The global occurrence rates of the gastric tumor have been documented by $41 \%$ and $60 \%$ for China and East Asia, respectively (Kamangar et al., 2006). Medical intervention is remained as the sole treatment mode by a contingently therapeutic effect (Jiang and Ajani, 2010) with the improved rates of success subsequent to post-operative adjuvant chemotherapy (Paoletti et al., 2010). The major chemotherapeutic media suggested for the gastric tumor is 5-fluorouracil (5-FU); however, its curative effects are usually curbed by a lower reaction rate and noticeable undesired effects. The severity of such complications usually restricts the dosage to an ineffective rate lowering the patients' life quality (Sastre et al., 2006, Tsai et al., 2018). As a result, it is necessary to devise a better method to raise the effectiveness of the present anti-cancer medications. Various studies show some substances discovered in plants, curative vegetables, and in some fruits which are helpful in fighting tumors; such studies have attracted a lot of attention in terms of their ability to find highly efficient chemo-preventive substances. Dietary or nutritional agents may induce the risk of prognosis following diagnosing the tumor, tumor expansion and the living standard while treating the tumor. Moreover, inhibiting the tumor is regarded as a logical methodology for dietary solutions. In reality, numerous efforts are made to extract bioactive agents from pharmaceutic herbs and make use of them in treating the disease (Al-Fatlawi et al., 2014). Cornus mas L. (Cornelian cherry) are regarded as the major fruit of forty verities of the family of Cornaceae (Hassanpour et al., 2011; Kurhajec et al., 2017). Being a

${ }^{1}$ Molecular Medicine Research Center, Research Institute of Basic Medical Sciences, ${ }^{2}$ Department of Clinical Biochemistry, Faculty of Medicine, ${ }^{3}$ Pistachio Safety Research Center, Rafsanjan University of Medical Sciences, Rafsanjan, ${ }^{4}$ Department of Clinical Biochemistry, Afzalipoor Faculty of Medicine, Kerman University of Medical Sciences, Kerman, Iran. *For Correspondence: mahmoodies@yahoo.com 
type of dogwood, A C. ma L. is indigenous to Asia and Southern Europe (Guleryuz et al., 1998; Vareed et al., 2006a). The bushes of cornelian cherry, in Iran, are located in the western regions, including Qazvin province and East Azerbaijan province (Hassanpour et al. , 2012; Hassanpour et al., 2011). Some studies have been conducted on the substance and physical attributes of cornelian cherry fruits (Rop et al., 2010; Tural and Koca, 2008). New fruits of cornelian cherry containing (vitamin C) ascorbic acid twice oranges demonstrate a potential of being used as food additives (Demir and Kalyoncu, 2003; Hassanpour et al., 2013). Such fruits have a large amount of phenols, tannins, anthocyanins, natural and organic acids, glucose and other antioxidant agents (Narimani-Rad et al., 2013; Yilmaz et al., 2009). In contrast, some juices extracted from pears, plums, cornelian cherries and apples contain a higher level of Calcium, yielding Calcium 10 times (323 $\mathrm{mg} / \mathrm{L}$ ) the rest of fruit drinks (14-77 $\mathrm{mg} / \mathrm{L})$. In addition, high amounts of $\mathrm{Mg}$ and $\mathrm{K}$ are found in Cornelian cherries, yet they contain a low amount of $\mathrm{Na}$ and the rest of vital minerals ( $\mathrm{Mn}, \mathrm{Cu}, \mathrm{Zn}$ and $\mathrm{Fe}$ ); moreover, the levels of their toxic factors are insignificant (Cindrić et al., 2012; Seeram et al., 2002). Cornelian cherries have been used in Iran, Central Asia and Caucasus as a traditional medicine for over a millennium (Asadov et al., 1990; Efendiyev, 1964). Galenicals are generated from the flowers and leaves, and the fruits are utilized to heal digestion issues, sore neck, chickenpox, measles, rickets, anemia, diseases of kidney (pyelonephritis) and liver (hepatitis A) in conventional and traditional medicine (Damirov et al., 1988; Tzitzin et al., 1963). The fruit's evaporated juice and juice are also utilized to treat diabetes. Furthermore, galenicals obtained from the dry fruit powder, leaves, dried and ground drupes are in general utilized in treating hemorrhoids and diarrhea (Asadov et al., 1990; Damirov et al., 1988). The seed oil and fruit flesh are utilized with success in treating hardto-cure wounds, colitis and stomach ulcers (Asadov et al., 1990; Damirov et al., 1988; Lewis and Elvin-Lewis, 1977). In addition, many fruits of the species of Cornus spp. are utilized to improve the functions of kidney and liver. It is also reported that the fruits have antihistamine, antibacterial, anti-microbial, anti-malarial and anti-allergic effects (Vareed et al., 2006a). Furthermore, the fruit' astringent attribute is regarded as a suitable cure for tumors (Vareed et al., 2006a), yet no information exists on the effect mechanism of Persian shallot on inhibiting tumors. Inducing apoptosis in cancer cells plays a crucial role in removing such cell lines. Therefore, the main reason for treating tumors is to adjust the growing of cancer cell lines and induce cell death with no harm to typical cell lines (Raicht et al., 1980). In a large number of tumor cells, apoptosis is inhibited, so the elective boost of apoptosis in tumor cells is currently regarded as the major method for treating tumors (Wainwright et al., 2014). In the current study, we mainly focused on the anticancer effects of the Cornus mass L. extract on gastric carcinoma cells (AGS) aiming at extending our knowledge about this compound and making us of its increase as an antitumor drug choice.

\section{Materials and Methods}

\section{Materials}

Penicillin-streptomycin, fetal bovine serum (FBS), trypsin enzyme and RPMI-1640 were provided by Gibco-BRL (Grand Island, NY, USA). Dimethyl sulfoxide (DMSO) and MTT were provided from Roche (Mannheim, Germany). DNase I and the annexin V-fluorescein isothiocyanate (FITC) apoptosis identification kit were provided from Sigma (St. Louis, MO, USA) and Ebioscience (San Diego, CA, USA), respectively.

\section{Hydroalcoholic Cornus mass L Preparation \\ The extract}

Cornus mass L got obtained. Herbalists at the Botany Department of Valiasr University of Rafsanjan, Iran, approved the types and genus of Cornus mass L. The freshly obtained bulbs (100 gr) were fully crushed and got soaked in $400 \mathrm{ml}$ of distilled ethanol/water $(75: 25 \mathrm{v} / \mathrm{v})$; afterwards, the mixture obtained was stirred. Following an incubation period of 48 hours at room temperature, the thorough solution got filtered in a Buchner funnel making use of a filter paper. Utilizing a vacuum freeze dryer, the solutions purified were concentrated and turned into a dry powder, and afterwards the concentrations desired were provided through dissolving in water the proper quantities of the powder (Hosseini et al., 2017).

\section{The cell culture process}

Iran's National Cell Bank (NCBI, Tehran, Iran) was the source for purchasing L929 and AGS cell lines. The culturing of the cells happened in the medium of RPMI-1640 accompanied by $100 \mu \mathrm{g} / \mathrm{ml}$ streptomycin, $100 \mathrm{IU} / \mathrm{ml}$ penicillin, $10 \%$ fetal bovine serum inactivated by heat (Bio-Rad, San Diego, CA, USA) at $37^{\circ} \mathrm{C}$ and moisturized atmosphere, with 5\% CO2 - 95\% $\mathrm{O}_{2}$. When the cultured cells reached the suitable confluence, they got subjected to passage (Karimabad et al., 2017a; Karimabad et al., 2017b).

\section{The viability test of cells, using the method MTT}

This test is capable of determining the reduction of MTT [2, 5- diphenyl - tetrazolium bromide and 3 - (4, 5-dimethyl thiazolyl)] (Sigma, USA) (making use of a colorimetric technique). The technique MTT is on the basis of producing a blue formazan product from mitochondrial dehydrogenase that indicates the normal functions of mitochondria and as a result the measurement method of the resulting cell viability and cytotoxicity. L929 and AGS cells got cultured in two plates of 96 wells at the density $2.5 \times 10^{3}$ of cells per well. Some densities of the compound of the new indole $(0-10 \mathrm{mg} / \mathrm{ml})$ as well as DMSO (the vehicle control) and identical doses of the primary indole were added as well. More incubation was conducted for 48 hours to 72 hours, the reagent MTT ( $5 \mathrm{mg} / \mathrm{L})$ got added to every well, and the incubation process was continued for 4 hours more. DMSO replaced the supernatant, and making use of a micro-plate scan spectrophotometer (ELISA reader, Bio Tek EIK 808, USA), the relative absorption got read at $570 \mathrm{~nm}$. The viable cell numbers were computed by suitable controls accounted for. The values for Mean \pm SD are demonstrated for three separate experiments. In addition, the inhibition 
rates got measured in accordance with the following formula: The rate of inhibition $=[$ (the control group's absorbance value - the test group's absorbance value)/ the control group's absorbance value] $\times 100$ percent (Sheikhrezaei et al., 2018).

\section{Cell analysis of apoptosis based on flow cytometric}

Making use of the apoptosis detection kit of Annexin V-FITC, PI and double staining with Annexin V-FITC were carried out for flow cytometry investigations. L929 and AGS cell lines got cultured for 24 hours and were incubated by the $\mathrm{IC}_{50}$ concentrations of Cornus mass L. The untreated or treated cells were cultured after 48 hours and 72 hours and were rinsed two times using PBS, and then they got suspended again in the binding buffer (buffer of calcium, 200 1l). The cells were added with Annexin V-FITC (5 11), and then 1011 of propidium iodide (PI) was added. The incubation of the samples was then conducted for 5 minutes in absence of light at $4^{\circ} \mathrm{C}$, and using a flow cytometer (BD FACS Calibur, BD Biosciences), they got tested (Mohammadizadeh et al., 2018).

\section{Statistical analysis}

For the statistical data analysis, the software SPSS (version 18) was utilized (Moosavi et al., 2013). All experiments were conducted thrice for every separate sample, and all results achieved were reported as the mean values of the three experiments (Derakhshan et al., 2012, Farangis et al., 2017). ANOVA test was also utilized for the data analysis task, and the p-value under 0.05 was regarded significant.

\section{Results}

The effect of the extract of Cornus mass L. on cell viability

To assess the inhibitive impacts of the Cornus mass L. extract on the development of L929 and AGS cells, the method MTT was utilized. The Hydroalcoholic Cornus mass L. extract at various concentrations $(0-10 \mathrm{mg} / \mathrm{ml})$ was used for 48 hours and 72 hours for the incubation of L929 and AGS cells. The results obtained showed that the Cornus mass L. extract lowered the viability of cells in AGS cells compared with the cells of L929, in a manner dependent on the respective dose (Figures 1, 2). In MTT test, the statistical analysis indicated that the Cornus mass L. extract curbed the growth of AGS cells significantly in comparison with L929 cells. Especially at the higher concentrations of Cornus mass L. (Figure 1), while discovered under the phase-contrast microscope, the quantity of colony-generating cells declined in culture (data are not demonstrated).

The $\mathrm{IC}_{50}$ values (assessed after 48 hours and 72 hours) of Cornus mass L. extract against with AGS cells

Table 1 Exhibits the IC50 values $(\mathrm{mg} / \mathrm{ml})$ of Cornus mass L extract against L929 and AGS Cell lines after 48 and $72 \mathrm{~h}$ of treatment.

\begin{tabular}{lcc}
\hline Cornus mass L & IC50 48h $(\mathrm{mg} / \mathrm{ml})$ & IC50 72h $(\mathrm{mg} / \mathrm{ml})$ \\
\hline L929 & 9.4 & 3.76 \\
AGS & 5.44 & 2.44 \\
\hline
\end{tabular}

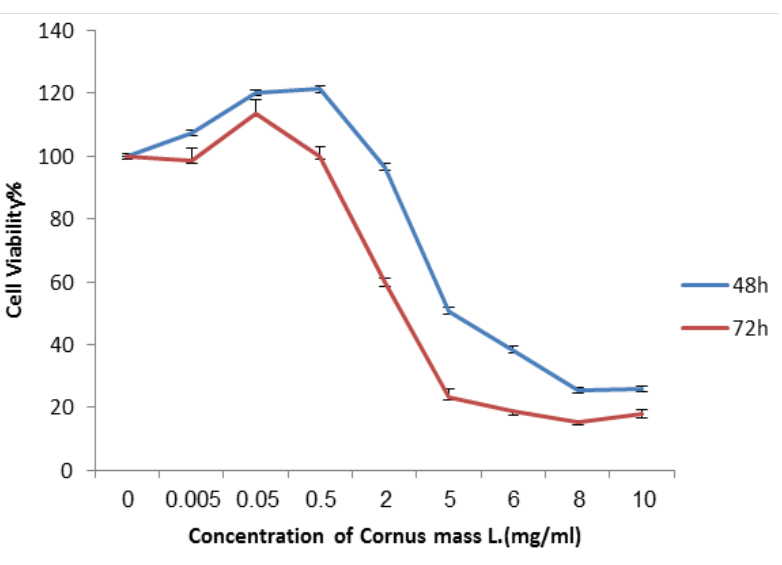

Figure 1. The Effects of Cornus mass L. on AGS Cells' Viability. The cells were exposed to various con $\neg$ centrations of Cornus mass L. in 48 hours and 72 hours, with the survival rates of the cells figured out by the MTT test. Every point of data yields a result average for three separate tests performed three times and reported as $\mathrm{M} \pm \mathrm{SD}$.

were 5.44 and $2.44 \mathrm{mg} / \mathrm{ml}$ and for L929 cells were 9.4 and $3.76 \mathrm{mg} / \mathrm{ml}(\mathrm{p} \leq 0.05)$. The results obtained showed that $\mathrm{IC}_{50}$ concentrations of the Cornus mass L extract lowered the viability of cells in AGS cells compared with the cells of L929. Toxicity was observed to be connected with morphological modifications, including the reduction in the cell volume and cell rounding (data are not demonstrated) and changes in the cell morphology characteristic of apoptosis was also investigated with an inverted microscope both AGS and 1,929 cell lines before and after treatment with $\mathrm{IC}_{50}$ concentrations of the Cornus mass L extract (Figure 3a,b,c,d).

The induction of apoptosis and necrosis in AGS cells by Cornus mass L. extract

The L929 cells and AGS cells got exposed to $\mathrm{IC}_{50}$ con $\neg$ centrations of the Cornus mass L. extract for 48 hours and 72 hours; the cells exposed were then stained

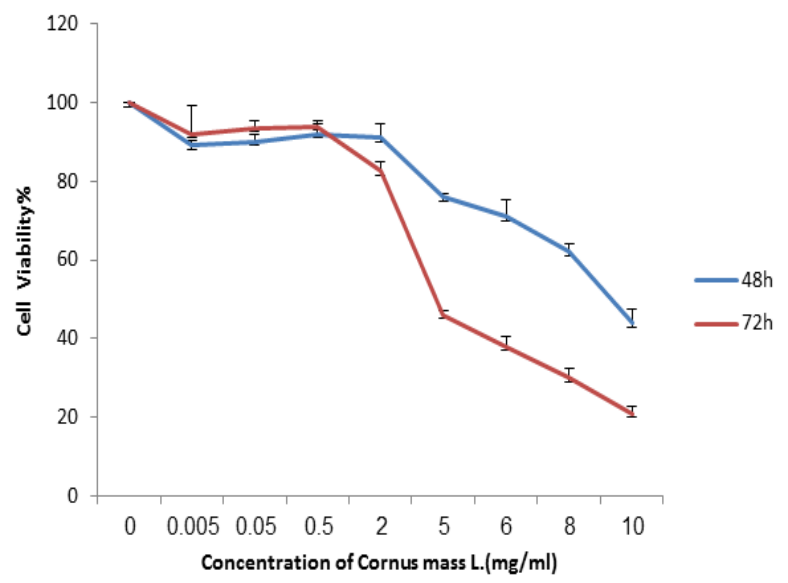

Figure 2. Effects of Cornus mass L. on L929 Cells' Viability. The cells were exposed to various concentrations of Cornus mass L. in 48 hours and 72 hours, with the survival rates of the cells figured out using the MTT test. Every point of data yields a result average for three separate tests performed three times and reported as $\mathrm{M} \pm \mathrm{SD}$.

Asian Pacific Journal of Cancer Prevention, Vol 20 
a
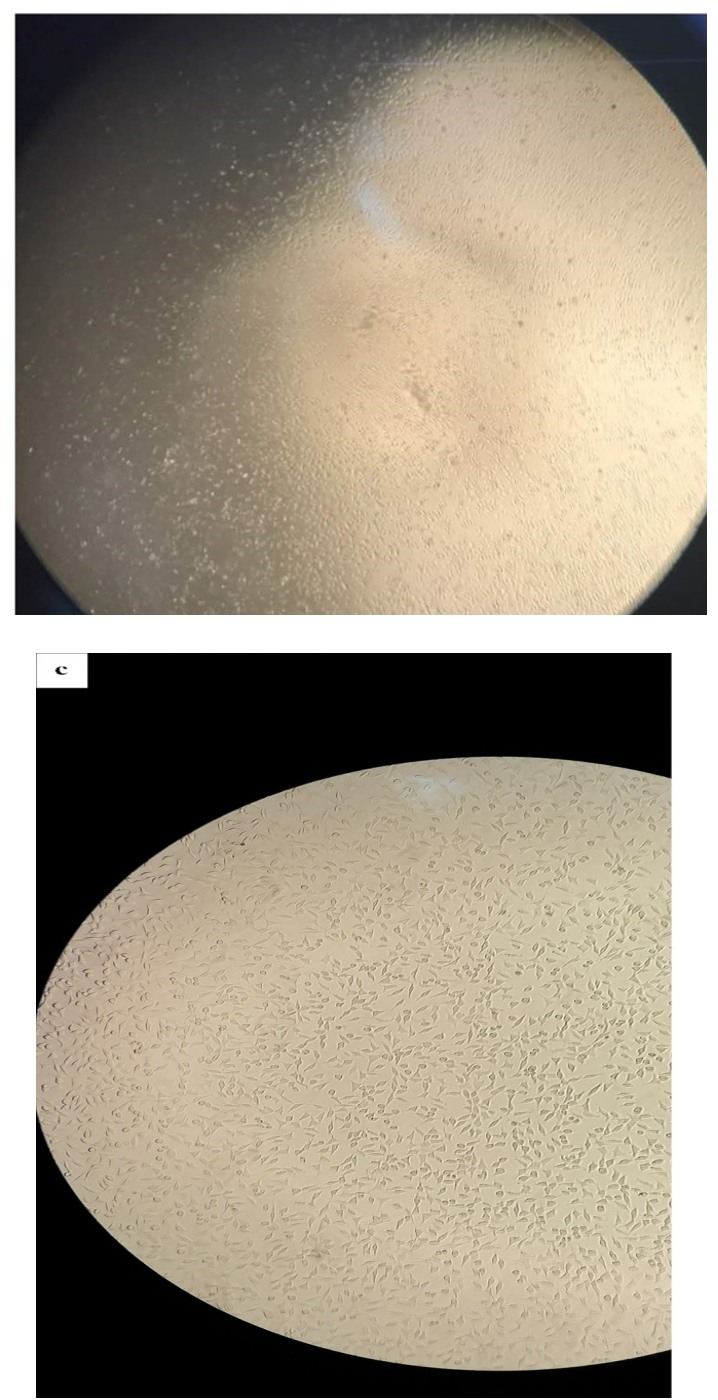

b
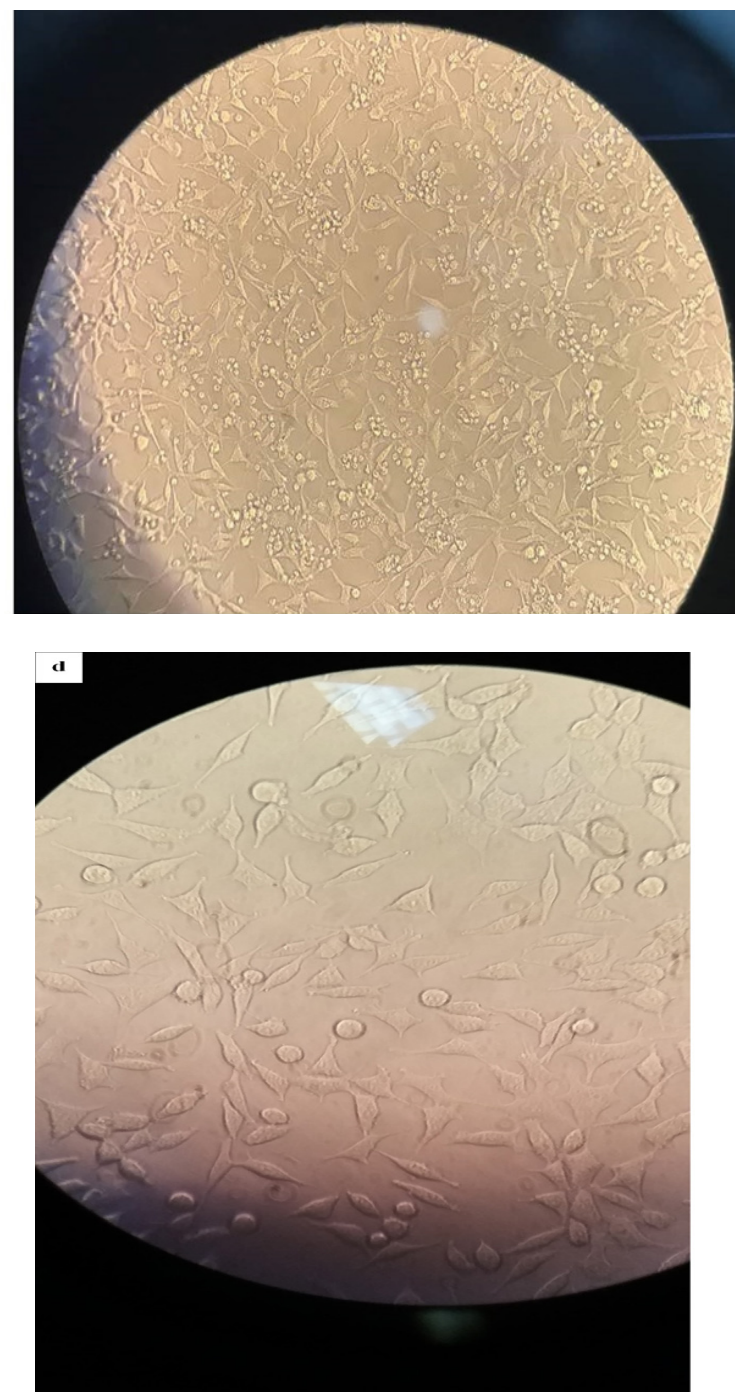

Figure 3. Morphological Changes on AGS(a-b) (control AGS (a), IC50AGS (b)) and L929 cells (c-d) (control L929 (c), IC50 L929 (d)) after exposure with Cornus mass L extract at 0 (untreated) and IC50 concentrations, respectively, that were observed with an inverted microscope.

Control

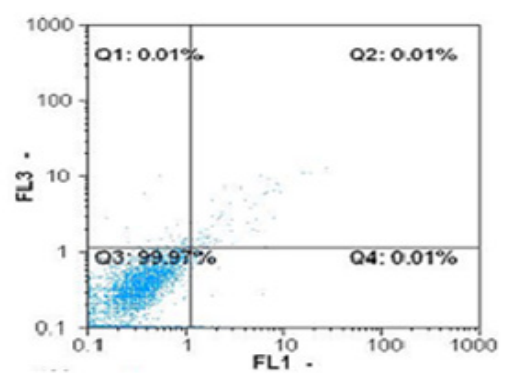

IC50 48h

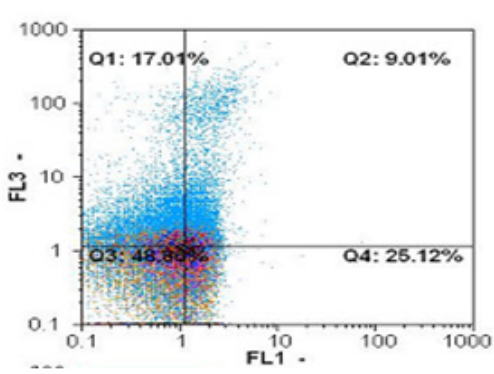

$1 \mathrm{C5072h}$

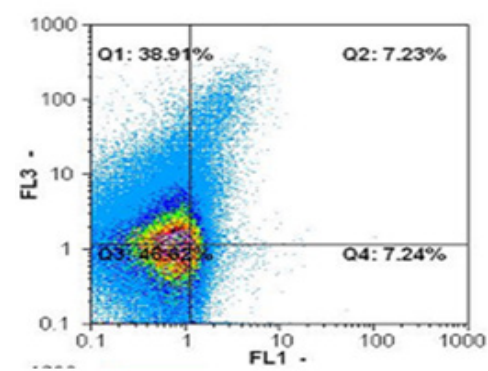

Figure 4. Inducing Apoptosis in AGS Cells Making Use of Cornus mass L. extract. Cells were exposed to IC50 con $\neg$ centrations of Cornus mass L. extract for 48 hours and 72 hours, being smeared with propidium iodide (PI) and Annexin V fluorescein isothiocyanate (FITC). Consequently, flow cytometry was utilized to quantify necrotic and apoptotic cells. Various subsidiary populations were determined as $\mathrm{Q}_{1}$, i.e. PI positive and Annexin V negative, i.e. necrotic cells; $Q_{2}$, i.e. Annexin positive V/PI double, i.e. late cells of apoptosis; $\mathrm{Q}_{2}$, Annexin negative V/PI double, i.e. ordinary living cells; and $\mathrm{Q}_{4}$, Annexin PI negative yet $\mathrm{V}$ positive, i.e. initial cells of apoptosis. $* \mathrm{P}<0.05$ indicates a noticeable deviation from the control cells.

by propidium iodide and annexin $\mathrm{V}$, and using flow cytometry, the apoptotic impacts of Cornus mass L. extract got measured on L929 and AGS cells. The analysis results of flow cytometry indicated that apoptosis was induced by the extract in AGS cells treated, compared with the control group; this result denotes that apoptosis-induced cell death has been incorporated in the toxicity induced by the extract (Figures 4, 5).

In Q3 region, normally living cells were seen (Figures 4,5). The sum of the cells in Q4 determined the early 


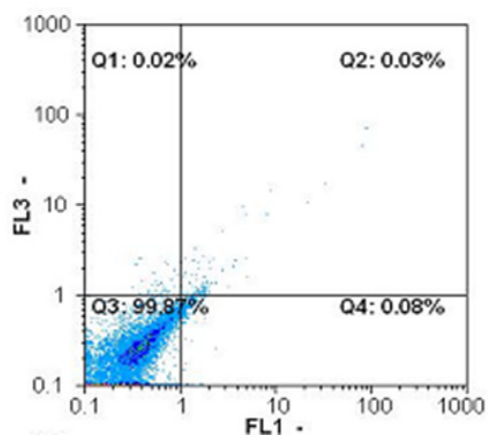

IC50 48h

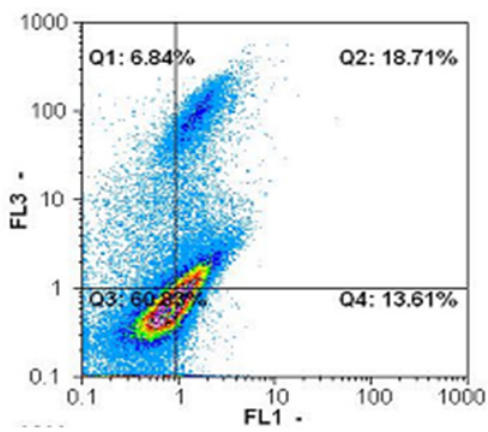

IC50 72h

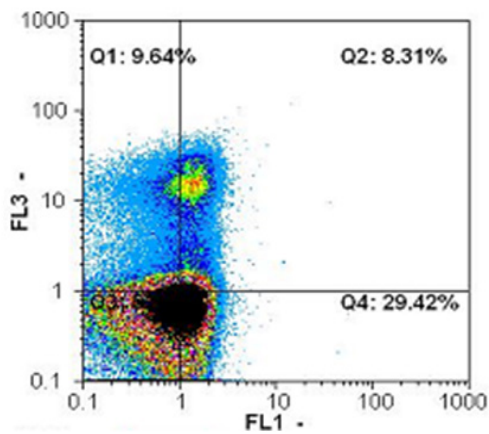

Figure 5. Inducing Apoptosis in L929 Cells Making Use of the Cornus mass L. extract. Cells were exposed to IC50 con-centrations of Cornus mass L. extract for 48 hours and 72 hours and smeared with propidium iodide (PI) and Annexin V fluorescein isothiocyanate (FITC). Next, flow cytometry was utilized to quantify necrotic and apoptotic cells. Various subsidiary populations were determined as Q1, PI positive but Annexin V negative, or necrotic cells; Q2, Annexin positive V/PI double, or late cells of apoptosis; Q3, Annexin V negative /PI double, or ordinary living cells; and Q4, PI negative but Annexin V positive, or initial cells of apoptosis. ${ }^{*} \mathrm{P}<0.05$ shows a noticeable deviation from the control cells.

apoptotic cells, and the necrotic and late apoptotic cells showed up principally in Q1 and Q2 areas, respectively (Figures 4,5) and also UL (NECROTIC CELLS), UR (late apoptotic cells), LL (normal live cells), LR( early apoptotic cells) demonstrated before (control) and after treatment with IC50 concentrations of the Cornus mass L extract both AGS and 1929 cell lines (Figures 6a,b).
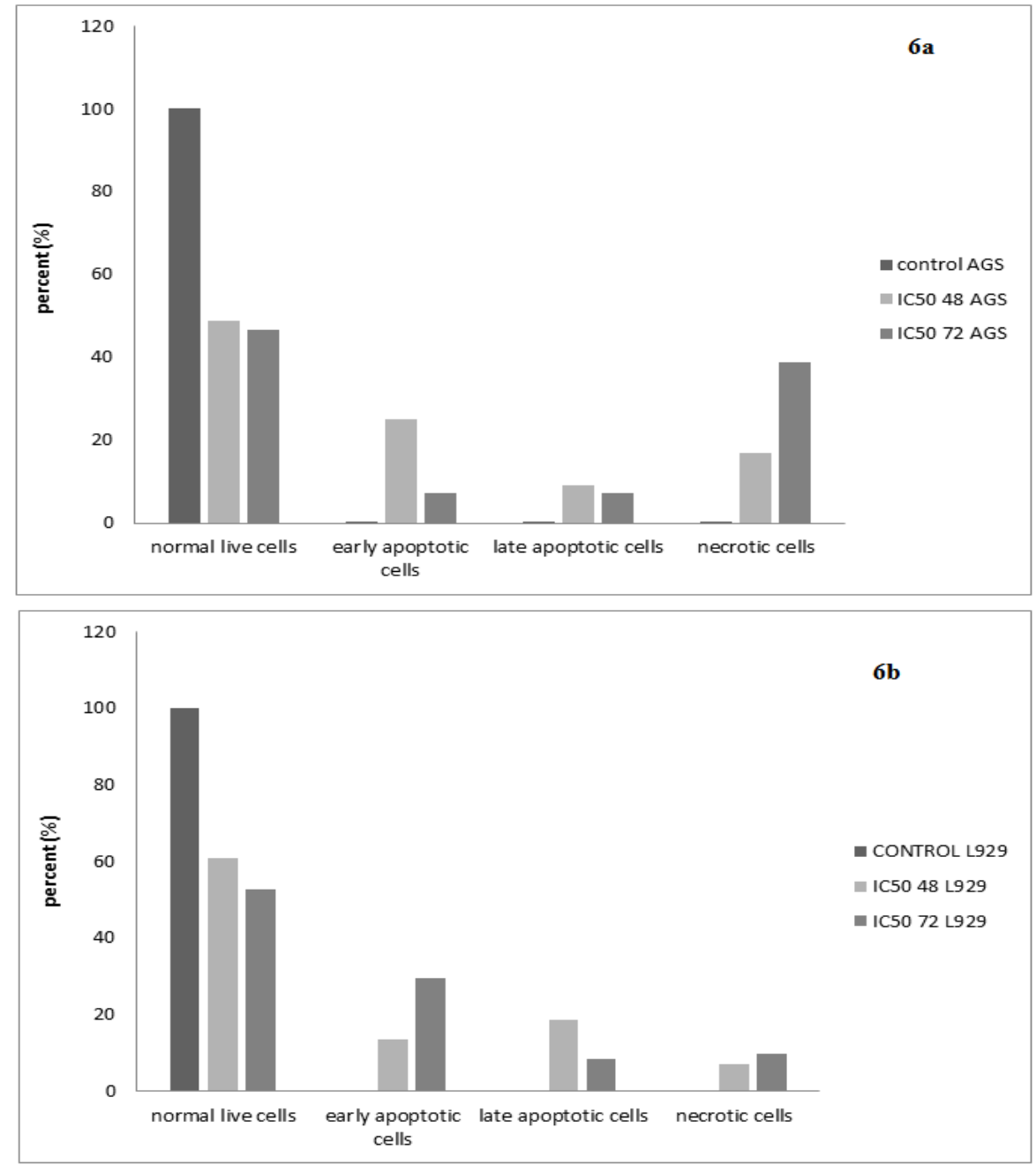

Figure 6. a, Indicates UL(necrotic cells), UR (late apoptotic cells), LL (normal live cells), LR( early apoptotic cells) in AGS cells after treatment with IC50 concentrations of Cornus mass L in comparison with untreated cells after 48,72 h; b, Indicates UL(necrotic cells), UR (late apoptotic cells), LL (normal live cells), LR( early apoptotic cells) in L929 cells after treatment with IC50 concentrations of Cornus mass L in comparison with untreated cells after 48,72 h. 


\section{Discussion}

Improving the efficiency of chemotherapy for stomach tumor is a requirement for improving patients' total survival rate and life quality (Jiang and Ajani, 2010; Tsai et al., 2018). In reality, against the advances in the classic tumor chemotherapy, the prediction chance of the advanced gastric cancer in patients is yet very low. Agent 5-FU, being anti-neoplastic in nature, is the first-line chemotherapy having a wide range of activity in gastro-intestinal tumors; however, like the majority of tumor medicines, its major disadvantage is the high level of toxicity and the low rate of therapeutic effect (O'Leary et al., 2018; Shah and Schwartz, 2001). As a result, it is urgently required that new therapeutic modalities be introduced for the gastric tumor. The major sources of novel therapeutic molecules against cancers are reported to be natural products (Zainodini et al., 2018) or chemically synthesized such as, metallodrugs (Aliabad et al., 2018; Mohammadizadeh et al., 2018; Rezaei et al., 2018), proline-derived compounds (Ramezani et al., 2017) and etc. Herbal materials are increasingly examined aimed at finding new anti-proliferative/ cytostatic compounds which are active. C. mas are applied as a part of therapeutic compounds in Classic Asian Medications (China, Korea). Cornus mass L extract is abundant in anti-oxidants and contains anthocyanins, flavonoids and ascorbic acid. Such ingredients protect lipids, DNA and proteins against the risk of free radicals (Habauzit and Morand, 2012; Kalt, 2005; Narimani-Rad et al., 2013). C. mas L. is of high significance with regard to decoration, being utilized in classic medicines to cure bleeding and heat stroke, cholera malaria, inflammatory bowel diseases, fever, urinary tract infections, kidney stone cancer, and diarrhea. Various researches have demonstrated that this plant has a significant role in inhibiting blood sugar, lipid profiles, atherosclerosis and declining fat aggregation in the liver. The plant possesses anti-inflammatory, anti-parasitic, antimicrobial, anti-oxidant as well as antitumor impacts; it also protects the cardiovascular system, kidneys and liver. Appling Cornelian Cherry has created a lot of value using this plant in food and pharmaceutical industries (Damirov et al., 1988; Tzitzin et al., 1963; Vareed et al., 2006b). The present research investigated the curative capacity of Cornus mass L. as an organic medicine for the gastric tumor. The current results demonstrated that Cornus mass $\mathrm{L}$ inhibits the development of gastric carcinoma cells; thus, it assuages the ingrained toxicity concerns. The primary research suggests that Cornus mass L possesses the capacity of reducing the proliferation of the tumor cell line and causing apoptosis in human's developed gastric tumor cells (Dai et al., 2013; Lee et al., 2009; Sheng et al., 2014). Therefore, in the present research, some concentrations of Cornus mass L were primarily examined to establish their separate $\mathrm{IC}_{50}$ values in comparison with AGS cells. Findings suggested $\mathrm{IC}_{50}$ value (evaluated following 48 hours and 72 hours) of Cornus mass L. extract and that of AGS cells were 5.44 and 2.44 $\mathrm{mg} / \mathrm{ml}$, respectively $(\mathrm{p} \leq 0.05)$. The results indicated that Cornus mass L. curbs significantly the AGS development in a concentration-based and time-based manner. These results are consistent with the past studies (Wu et al., 2010; Zhuo et al., 2009). It has also been determined to be synergetic in a statistically significant way. Preceding researches have reported the cytotoxic effects of the extracts of some Cornus types. The anti-proliferative in vitro effects of such extracts were explicated for various cell types (MCF-7, MDA-MB-231-breast tumor, HCT116colon tumor, and HT29). The anti-proliferative effects were explicated for certain Cornaceae-detached pure compounds, including the derivatives of betulinic acid, morroniside as well as other nonpolar compounds, and also anthocyanins, including delphinidin 3-O-rutinoside and delphinidin 3-O-glucoside (Chen et al., 2014; Graziose et al., 2012; Vareed et al., 2006b). Modulating critical enzymes, anti-oxidant effects, and the increase in antibody treatment and apoptosis are central to tumor chemotherapy. Anti-tumor effects and the capability of certain polyphenols in decreasing or inhibiting the DNA damage are well recorded, i.e. polyphenols inducing cancer necrosis and factor-connected apoptosis-causing ligand (TRAIL) (Szliszka and Krol, 2015). Cytotoxic impacts of the ethanolic extraction of the ripe and unripe Cornelian cherry fruits were measured at the concentrations of 250 , 200, 150,100, 50,10 $\mu \mathrm{g} / \mathrm{mL}$ on MCF1 (breast cancer), Hep G2 (liver cancer), CHO of hamster's normal ovary cells by 5-diphenyltetrazolium bromide (MTT) and 3-(4,5-dimethylthiazolyl-2)-2 assay. The results indicated that the suppressive impacts of the extract were time and dose-dependent, and that there existed a line. In addition, the unripe fruit showed more stable cytotoxic impacts compared with the ripe one (Rezaei et al., 2014). This anti-cancer effect of the ethanolic extract of Cornelian cherry is stronger than that of the fruit's aqueous extract (Turker et al., 2012). Cornelian cherry's anthocyanins inhibited the development of human's colon cancer MCF1 (breast), 116 (HCT-116), SF-268 (CNS), AGS (stomach) and NCL-H460 (lung) tumor cell lines. It has also been demonstrated that the Cornelian cherry extract has cytotoxic effects (Šavikin et al., 2009). In another research, the researchers showed the extract's significant potential for lowering the cell development of MCF-7 (tumor cell lines of the human breast) in the time and dose-dependent ways (Rezaei et al., 2014; Yousefi et al., 2015). At the concentration $500 \mu \mathrm{g}^{\prime \prime} \mathrm{mL}$ '1, the abstract inhibited the cell development over $60 \%$ after 24 hours, 48 hours and 72 hours from the time the treatment started, so the results are in line with the results of the current paper.

Conclusions: Water extracts of Cornus mass L. were examined in terms of their probable in vitro anti-proliferative effects on carcinoma AGS cells of human breasts. The current findings demonstrate the time and dose-dependent anti-proliferative impacts of the entire extracts examined. The encouraging conclusions of the current study call for more elaborated research to be conducted on some other carcinoma cells, emphasizing intracellular working (s) of the cell development inhibitive effects.

\section{Conflict of Interest}

None of the authors of the present study declared the 
conflict of interest.

\section{Acknowledgments}

This project was financially supported by a grant from the University of Medical Sciences

\section{References}

Al-Fatlawi AA, Al-Fatlawi AA, et al (2014). Rice bran phytic acid induced apoptosis through regulation of $\mathrm{Bcl}-2 / \mathrm{Bax}$ and p53 genes in HepG2 human hepatocellular carcinoma cells. Asian Pac J Cancer Prev, 15, 3731-6.

Aliabad HB, Falahati-pour SK, Ahmadirad H, et al (2018). Vanadium complex: an appropriate candidate for killing hepatocellular carcinoma cancerous cells. BioMetals, 31, 981-90.

Asadov S, Ibrahimov Z, Sadikhova S (1990). Zoghal (Cornus mas L.) (in Turkish).

Elm, BakuChen JP, Xu DG, et al (2014). Discrepancy between the effects of morronside on apoptosis in human embryonic lung fibroblast cells and lung cancer A549 cells. Oncol Lett, 7, 927-32.

Cindrić IJ, Zeiner M, Krpetić M, Stingeder G (2012). ICP-AES determination of minor and major elements in Cornelian cherry (Cornus mas L.) after microwave assisted digestion. Microchem J, 105, 72-6.

Dai J, Shen J, Pan W, Shen S, Das UN (2013). Effects of polyunsaturated fatty acids on the growth of gastric cancer cells in vitro. Lipids Health Dis, 12, 71.

Damirov I, Prilipko L, Shukurov D, Kerimov Y (1988). Medicinal plants of Azerbaijan. Baku: Maaraif.

Demir F, Kalyoncu IH (2003). Some nutritional, pomological and physical properties of cornelian cherry (Cornus mas L.). $J$ Food Eng, 60, 335-41.

Derakhshan R, Arababadi MK, Ahmadi Z, et al (2012). Increased circulating levels of SDF-1 (CXCL12) in type 2 diabetic patients are correlated to disease state but are unrelated to polymorphism of the SDF-1 $\beta$ gene in the Iranian population. Inflammation, 35, 900-4.

Efendiyev I (1964). History of medicine in Azerbaijan from ancient times to the 19th Century. Izdatelstvo Akademii Nauk Baku.

Farangis F, Majid M, Gholamhossein H, et al (2017). CC chemokines CCL2, CCL3, CCL4 and CCL5 are elevated in osteoporosis patients. J Biomed Res, 31, 468.

Graziose R, Rojas-Silva P, Rathinasabapathy T, et al (2012). Antiparasitic compounds from Cornus florida L. with activities against Plasmodium falciparum and Leishmania tarentolae. J Ethnopharmacol, 142, 456-61.

Guleryuz M, Bolat I, PIRLAK L (1998). Selection of table cornelian cherry (Cornus mas L.) types in Çoruh Valley. Turk J Agric For, 22, 357-64.

Habauzit V, Morand C (2012). Evidence for a protective effect of polyphenols-containing foods on cardiovascular health: an update for clinicians. Ther Adv Chronic Dis, 3, 87-106.

Hassanpour H, Hamidoghli Y, Samizadeh H (2012). Some fruit characteristics of Iranian cornelian cherries (Cornus mas L.). Notulae Botanicae Horti Agrobotanici Cluj-Napoca, 40, 247.

Hassanpour H, Hamidoghli Y, Samizadeh H (2013). Estimation of genetic diversity in some Iranian cornelian cherries (Cornus mas L.) accessions using ISSR markers. Biochem Syst Ecol, 48, 257-62.

Hassanpour H, Yousef H, Jafar H, Mohammad A (2011). Antioxidant capacity and phytochemical properties of cornelian cherry (Cornus mas L.) genotypes in Iran. Sci
Hortic, 129, 459-63.

Hosseini FS, Falahati-pour SK, Hajizadeh MR, et al (2017). Persian shallot, Allium hirtifolium Boiss, induced apoptosis in human hepatocellular carcinoma cells. Cytotechnology, 69, 551-63.

Jemal A, Siegel R, Xu J, Ward E (2010). Cancer statistics. CA Cancer J Clin, 60, 277-300.

Jiang Y, Ajani JA (2010). Multidisciplinary management of gastric cancer. Curr Opin Gastroenterol, 26, 640-6.

Kalt W (2005). Effects of production and processing factors on major fruit and vegetable antioxidants. J Food Sci, 70, 11-9.

Kamangar F, Dores GM, Anderson WF (2006). Patterns of cancer incidence, mortality, and prevalence across five continents: defining priorities to reduce cancer disparities in different geographic regions of the world. J Clin Oncol, 24, 2137-50.

Karimabad MN, Mahmoodi M, Jafarzadeh A, et al (2017a). The novel Indole-3-formaldehyde (2-AITFEI-3-F) is involved in processes of apoptosis induction?. Life Sci, 181, 31-44.

Karimabad MN, Mahmoodi M, Jafarzadeh A, et al (2017b). Evaluating of OCT-4 and NANOG was differentially regulated by a new derivative indole in leukemia cell line. Immunol Lett, 190, 7-14.

Kurhajec S, Franc A, Dolezel P, Sabadkova D (2017). Quality by design approach: antioxidant activity of the tablets containing cornelian cherry fruits in relation to their composition and physical properties. Pharm Dev Technol, 22, 881-8.

Lee SE, Lim JW, Kim H (2009). Activator protein-1 mediates docosahexaenoic acid-induced apoptosis of human gastric cancer cells. Ann N Y Acad Sci, 1171, 163-9.

Lewis W, Elvin-Lewis M (1977). Medical botany New York. John Wiley and Sons, 1, pp 78-81.

Mohammadizadeh F, Falahati-pour SK, Rezaei A, et al (2018). The cytotoxicity effects of a novel $\mathrm{Cu}$ complex on MCF-7 human breast cancerous cells. BioMetals, 31, 233-42.

Moosavi SR, Khorramdelazad H, Amin M, et al (2013). The SDF-1 3'A genetic variation is correlated with elevated intra-tumor tissue and circulating concentration of CXCL12 in Glial tumors. J Mol Neurosci, 50, 298-304.

Narimani-Rad M, Lotfi A, Abbasi MM, Abdollahi B (2013). The effect of Cornelian Cherry (Cornus mas L.) extract on serum ghrelin and corticosterone levels in Rat model. Group, 329, 190-2.

O'Leary BR, Houwen FK, Johnson CL, et al (2018). Pharmacological ascorbate as an adjuvant for enhancing radiation-chemotherapy responses in gastric adenocarcinoma. Radiat Res, 189, 456-65.

Paoletti X, Oba K, Burzykowski T, et al (2010). Benefit of adjuvant chemotherapy for resectable gastric cancer: a meta-analysis. JAMA, 303, 1729-37.

Raicht RF, Cohen BI, Fazzini EP, Sarwal AN, Takahashi M (1980). Protective effect of plant sterols against chemically induced colon tumors in rats. Cancer Res, 40, 403-5.

Ramezani M, Ramezani M, Hassanshahi G, et al (2017). Does the novel class of (2R, 4S)-N-(2, 5-Difluorophenyl)4-Hydroxy-1-(2, 2, 2-Trifluoroacetyl) Pyrrolidine-2Carboxamide's have any effect on cell viability and apoptosis of human hepatocellular carcinoma cells?. Int J Cancer Manag, 10, e8413.

Rezaei A, Falahati-pour SK, Mohammadizadeh F, et al (2018). Effect of a Copper (II) complex on the induction of apoptosis in human hepatocellular carcinoma cells. Asian Pac J Cancer Prev, 19, 2877-84.

Rezaei F, Shokrzadeh M, Majd A, Nezhadsattari T (2014). Cytotoxic effect of hydroalcoholic extract of Cornus mas L. fruit on MCF7, HepG2 and CHO cell line by MTTAssay. J Mazandaran Univ Med Sci, 24, 130-8. 
Rop O, Mlcek J, Kramarova D, Jurikova T (2010). Selected cultivars of cornelian cherry (Cornus mas L.) as a new food source for human nutrition. Afr J Biotechnol, 9, 1205-10.

Sastre J, Garcia-Saenz JA, Diaz-Rubio E (2006). Chemotherapy for gastric cancer. World J Gastroenterol, 12, 204-13.

Šavikin K, Zdunić G, Janković T, et al (2009). In vitro cytotoxic and antioxidative activity of Cornus mas and Cotinus coggygria. Nat Prod Res, 23, 1731-9.

Seeram NP, Schutzki R, Chandra A, Nair MG (2002). Characterization, quantification, and bioactivities of anthocyanins in Cornus species. J Agric Food Chem, 50, 2519-23.

Shah MA, Schwartz GK (2001). Cell cycle-mediated drug resistance: an emerging concept in cancer therapy. Clin Cancer Res, 7, 2168-81.

Sheikhrezaei Z, Heydari P, Farsinezhad A, et al (2018). A new indole derivative decreased SALL4 gene expression in acute Promyelocytic leukemia cell line (NB4). Iran Biomed $J, 22,99$.

Sheng H, Li P, Chen X, et al (2014). Omega-3 PUFAs induce apoptosis of gastric cancer cells via ADORA1. Front Biosci (Landmark edition), 19, 854-61.

Szliszka E, Krol W (2015). Natural polyphenols target the tumor necrosis factor-related apoptosis-inducing ligand (TRAIL) signaling pathway for cancer chemoprevention. Foods and Dietary Supplements in the Prevention and Treatment of Disease in Older Adults: Elsevier, pp 119-34.

Tsai CL, Chiu YM, Ho TY, et al (2018). Gallic acid induces apoptosis in human gastric adenocarcinoma cells. Anticancer Res, 38, 2057-67.

Tural S, Koca I (2008). Physico-chemical and antioxidant properties of cornelian cherry fruits (Cornus mas L.) grown in Turkey. Sci Hortic, 116, 362-6.

Turker AU, Yildirim AB, Karakas FP (2012). Antibacterial and antitumor activities of some wild fruits grown in Turkey. J Biosci Bioeng, 26, 2765-72.

Tzitzin N, Anichkov C, Itzkov N (1963). Atlas of medicinal plants of USSR. Gosmed Izd. Moscow.

Vareed SK, Reddy MK, Schutzki RE, Nair MG (2006). Anthocyanins in Cornus alternifolia, Cornus controversa, Cornus kousa and Cornus florida fruits with health benefits. Life Sci, 78, 777-84.

Wainwright DA, Chang AL, Dey M, et al (2014). Durable therapeutic efficacy utilizing combinatorial blockade against IDO, CTLA-4, and PD-L1 in mice with brain tumors. Clin Cancer Res, 20, 5290-301.

Wu Q, Yu J, Liu Y, Kang W, Guo W (2010). Effect of combination of docosahexaenoic acid and fluorouracil on human gastric carcinoma cell strain MGC803. Zhongguo Yi Xue Ke Xue Yuan Xue Bao, 32, 65-70.

Yilmaz KU, Ercisli S, Zengin Y, Sengul M, Kafkas EY (2009). Preliminary characterisation of cornelian cherry (Cornus mas L.) genotypes for their physico-chemical properties. Food Chem, 114, 408-12.

Yousefi B, Abasi M, Abbasi MM, Jahanban-Esfahlan R (2015). Anti-proliferative properties of Cor Asian Pac J Cancer Prev. nus mass fruit in different human cancer cells. Asian Pac J Cancer Prev, 16, 5727-31.

Zainodini N, Hassanshahi G, Hajizadeh M, et al (2018). Nisin induces cytotoxicity and apoptosis in human asterocytoma cell line (SW1088). Asian Pac J Cancer Prev, 19, 2217-22.

Zhuo Z, Zhang L, Mu Q, et al (2009). The effect of combination treatment with docosahexaenoic acid and 5-fluorouracil on the mRNA expression of apoptosis-related genes, including the novel gene BCL2L12, in gastric cancer cells. In Vitro Cell Dev Biol Anim, 45, 69-74.

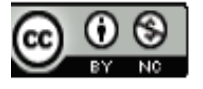

This work is licensed under a Creative Commons AttributionNon Commercial 4.0 International License. 